\title{
DESCRIPTION OF A NEW PLUMED PARTRIDGE FROM SONORA.
}

\section{BHY ROBER'T RIDGWAY.}

Callipepla elegans bensoni, subsp. nov.

Subsp. Char.-Similar to C. elegans (LEss.), ${ }^{*}$ but throat with black, decidedly predominating over white; rusty markings of hind neck, scapulars, tertials, and flanks mnch less bright; lower back, rump, and upper tail-coverts decidedly less brown or olivaceous, and white spots on lower brast and belly larger; the female with erest uniform dusky-blackinstead of mainly light tawny; the throat thickly streaked or spotted with blackish, instead of marked with very narrow shaftstreaks only; back nearly plain grayish, instead of being distinctly barred, and lighter spots on lower parts much larger.

Adult male (type, No. 110502 , Campos, Sonora; Lieut. H. C. Benson, U.S.A.): A conspicuous crest of lengthened, rather narrow, feathers of a plain ochraceous-buff color, with deep brown shafts. Forehead, fore part and sides of erown, and lores, gray, narrowly streaked with black; feathers of chin and throat black, with narrow terminal margins of white and spotted with same beneath surface; feathers of cheeks and sides of nape similar, but also edged with white, producing more streaked appearance; feathers of nape pale-grayish, each marked with a mesial wedge-shaped streak, the narrow basal portion of which is blackish, the wider terminal portion rusty-chestnut or hazel; feathers of lower hind-neck and sides of neck ash-gray laterally, bright hazel medially, these latter markings changing ou sides of chest to vinaceouscinnamon, and become gradually smaller and more guttate toward front part of chest, which is plain ash-gray ; back plain ash-gray, tinged with olive posteriorly, the lower back, rump, and upper tail-coverts plain olivaceous-gray; scapulars light hazel or dull rusty centraily, then grayish, the edges rather broad white; tertials similar, but merely tinged with hazel, the general light brownish color of exposed portion tinely mottled or freckled with darker, the whitish edging on outer webs indistinct or broken; prevailing color of wings olive-grayish, but uppermost larger coverts marked with hazel and white, like scapulars; primaries plain slate-gray, with dusky shafts and somewhat heavy edges; tail deep bluish-gray, or plumbeous, with black shafts. Sides and flanks dull grayish and vinaceous-cinnamon, the latter in form of large, but rather ill-defined, mesial guttate marks, the edges of the feathers marked with oval or elliptical spots of white, these changing on uppermost feathers to streaks, and toward belly to cireular spots, the vinaceous-cinnamon disappearing altogether on the breast and belly, which are

*Ortyx elegans Less., Cent. zool., 1832, pl. 61. Callipepla elegans Gould, Mon. Odont., 1850, pl. 18. 
dull ash.gray, coarsely spotted with white; femoral region dull white, with large, somewhat sagittate, stripes of grayish-brown; under tailcoverts buffy-white or very pale buff, marked with broad mesial, somewhat wedge-shaped, stripes of deep olive, changing to plumbeous on longer feathers. Bill deep black; legs and feet deep horn-color (more grayish in life?). Length (skin), 9.50 ; wing, 4.95; tail, 4.00; tarsus, 1.30.

Adult female (No. 110504, Campos, Sonora; Lieut. H. C. Benson, U. S. A.): Very different in color from the male. Crest smaller than in male, uniform dull black ; forehearl, \&c., dull brownish grey (more brownish posteriorly) streaked with black, the streaks growing much broader and the ground-color paler on occipat; sides of nape and sides of neck dull whitish spotted with brownish black; chin, throat, and cheeks white, speckled with black, each feather having a central guttate spot of the latter and a broad margin of the former color; ear-coverts uniform deep hair-brown, producing a distinct spot; back dull gray, mi. nutely mottled or zigzagged with lighter and darker (but not barred), the general color changing to a more olivaceous gray on lower back and rump ; upper tail-coverts brownish gray, coarsely zigzagged with whitish, the concealed portion of the feathers more uniform and more bluish gray ; tail plumbeous, but upper surface minutely mottled with grayish brown and whitish. Scapulars dark brown, mottled with paler, many of the feathers broadly, but more or less irregularly margined with dull, buffy whitish, producing a coarsely blotched appearance; tertials similar, but light buffy edging to inner webs, broader and very sharply defined; wings in general coarsely mottled, light grayish brown, dusky and pale cinnamon-buffy, the latter forming irregular borders to the larger coverts; primaries as in the male (plain slate-gray with hoary edges); chest light brownish gray (more decidedly brownish next to throat), coarsely spotted with dull whitish, these spots growing gradually larger posteriorly, until on lower breast and middle of belly the prevailing color is dull white, narrowly barred with grayish brown ; sides and flanks dull white, tinged with buffy, and broadly striped with hair.brown ; fem. oral region more distinctly buffy, but marked with more pointed stripes; lower tail-coverts buffy whitish, marked with broad mesial stripes of hair-brown, changing to slate-gray on longer feathers. Bill black; feet dark horn-color. Length (skin), 8.50 ; wing, 4.50 ; tail, 3.75 ; tarsus, 1.20 ; middle toe, 1.10 .

Two other adult males are essentially like the type, but differ in some details, as follows:

No. 110501 has the crest of a much deeper color, the tint being cinnamon-buff; the crissum and under tail-coverts are pale buff, with narrower mesial streaks.

No. 110503 has the crest rather paler than in the type, and the black of the chin and throat is nearly uniform, owing to wearing away of the white terminal margin. 
Another female (No. 110506) differs from that described in having the crest less deeply black, the shorter feathers having an indistinct freckling of brown, and the upper tail coverts are much more distinctly marked with buffy whitish, in the form of irres;ular bars.

The five specimens upon which this new race is based have been carefully compared with six examples (four males and two females) of true C. elegans from Mazatlan, and the difference noted in the above diagnosis found to be constant. A pair of typical $C$. elegans are well tigured in Gould's Monograph of the Odontophorinæ, the figures in question showing unmistakably the characters of the Mazatlan bird, even to the light-brown crest of the female, which, however, is represented as being unicolored. That this is an error is evident, however, from the text, which describes the erest as brown, "crossed with zigzag markings of a darker color," thus agreeing with the specimens which have been examined by me.

Measurements of the two forms compare as follows:

C. ELEGANS.

\begin{tabular}{|c|c|c|c|c|c|c|c|c|}
\hline $\begin{array}{l}\text { Mus. } \\
\text { No. }\end{array}$ & $\begin{array}{l}\text { Col- } \\
\text { lector's } \\
\text { No. }\end{array}$ & $\begin{array}{l}\text { Sex } \\
\text { and } \\
\text { age. }\end{array}$ & Locality. & Date. & Wing. & Tail. & $\begin{array}{l}\text { Tar- } \\
\text { sus. }\end{array}$ & $\begin{array}{l}\text { Middle } \\
\text { toe. }\end{array}$ \\
\hline $\begin{array}{l}37341 \\
23871 \\
23873 \\
\end{array}$ & $\begin{array}{r}267 \\
\cdots \\
158\end{array}$ & $\begin{array}{l}\text { ơad. } \\
\text { ơad. } \\
\text { ơad. } \\
\text { ơad. }\end{array}$ & 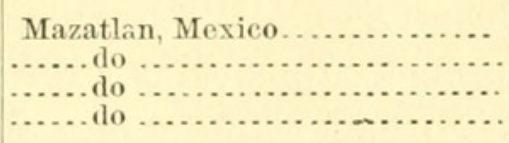 & $\begin{array}{l}\text { June -, } 1861 \\
\text { June - } 1861 \\
\text { A pr. 21, }\end{array}$ & $\begin{array}{l}4.50 \\
4.40 \\
4.50 \\
4.60\end{array}$ & $\begin{array}{l}\text { 3. } 35 \\
3.50 \\
\text { 3. } 51 \\
3.45\end{array}$ & $\begin{array}{l}\text { 1. } 20 \\
1.20 \\
1.20 \\
1.25\end{array}$ & $\begin{array}{l}\text { 1. } 10 \\
\text { 1. } 15 \\
1.10 \\
1.10\end{array}$ \\
\hline & & & Average.. & & 4.50 & 3.45 & 1. 21 & 1. 11 \\
\hline
\end{tabular}

C. ELEGANS BENSONI.

\begin{tabular}{|c|c|c|c|c|c|c|c|c|}
\hline $\begin{array}{l}110502 \\
110501 \\
110503\end{array}$ & $\begin{array}{r}9 \\
3 \\
13\end{array}$ & $\begin{array}{l}\text { sad. } \\
\text { sad. } \\
\text { sad. }\end{array}$ & 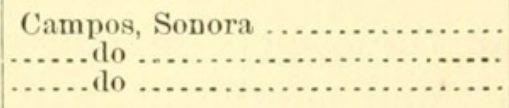 & $\begin{array}{l}\text { Feb. } \quad 3,1887 \\
\text { Feb. } 3,1887 \\
\cdots\end{array}$ & $\begin{array}{l}\text { 4. } 50 \\
\text { 4. } 40 \\
\text { 4. } 70\end{array}$ & $\begin{array}{l}3.75 \\
3.50 \\
3.85\end{array}$ & $\begin{array}{l}\text { 1. } 20 \\
1.20 \\
1.20\end{array}$ & $\begin{array}{l}\text { 1. } 10 \\
\text { 1. } 10 \\
1.15\end{array}$ \\
\hline & & & Average & & 4. 53 & 3. 70 & 1. 20 & 1. 12 \\
\hline
\end{tabular}




\section{$2 \mathrm{BHL}$ Biodiversity Heritage Library}

Ridgway, Robert. 1887. "Description of a new plumed partridge from Sonora." Proceedings of the United States National Museum 10(617), 148-150.

https://doi.org/10.5479/si.00963801.617.148.

View This Item Online: https://www.biodiversitylibrary.org/item/32314

DOI: https://doi.org/10.5479/si.00963801.617.148

Permalink: https://www.biodiversitylibrary.org/partpdf/23718

\section{Holding Institution}

Smithsonian Libraries

\section{Sponsored by}

Smithsonian

\section{Copyright \& Reuse}

Copyright Status: NOT_IN_COPYRIGHT

This document was created from content at the Biodiversity Heritage Library, the world's largest open access digital library for biodiversity literature and archives. Visit BHL at https://www.biodiversitylibrary.org. 